\title{
ケナフ乾燥粉末の食品への利用
}

\author{
細見和子 $*$. 岡田祐季 $*$. 森下敏子 $*$ 稲垣 寬 $* *$ \\ $(*$ 神戸女子短期大学食物栄養学科 $\cdot * *$ 神戸女子大学・ケナフ協議会会長 $)$
}

\section{Utilization of Dried Kenaf (H. Cannabinus) Leaves to the Meals}

\author{
Kazuko Hosomi*, Yuki Okada*, Tosiko Morisita*, Hirosi Inagaki**
}

*Kobe Women's Junior College, 4-7-2,

Minatojimanakamachi, Chuo-ku, Kobe-shi, Hyogo, 650-0046

**Kobe Women's University, 2-1, Higashisuma, Suma-ku, Kobe-shi, Hyogo, 654-8585

*テ650-0046 兵庫県神戸市中央区港島中町4-7-2

**⿳亠二冖丁6 $654-8585$ 兵庫県神戸市須磨区東須磨 $2-1$

Kenaf (cannabinaus) is one of annual plants which belong to Malyales, Hibiscus L. Recently "Kenaf" draws one's attention for prevention of global warming and cleaning muddy water.

The dried kenaf leaves contain about a lot of calcium and dietary fibers.

Minerals, particularly calcium, are effective for the formation of bones and teeth, and dietary fibers contribute highly to our health.

We tried to add the dried kenaf leaves in meals to improve the nutritional balance.

The kenaf leaves were obtained at the Biotechnology Center of Kobe Women's university in November of 1998. The kind of kenaf is "green skin NO.3" these seeds imported from China.

The result is following.

We tried from one to three percent of dried green kenaf leaves powder mixing with cereals'powder. And made breads, sponge cakes, steamed cakes, dumplings and others.

1. Over $3 \%$ contents of kenaf leaves powder indicated bitterness.

2. The most suitable contents of kenaf powder for sponge cake and steamed cake were $3 \%$, and for another foodstuffs were $1 \%$.

3. When $1 \%$ kenaf powder added to flour, the calcium contents 1.6 times and dietary fibers shows 2 times more than original flour.

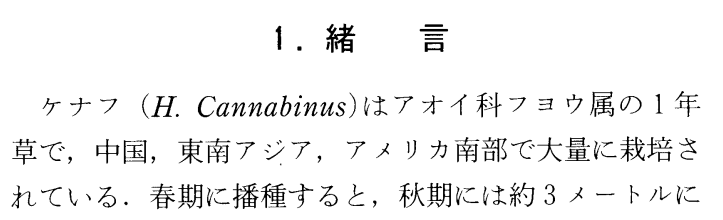

成長する。ケナフは, 地球温暖化の防止 ${ }^{1)}$, 水の浄化作 用2などの環境改善の効果をもたらす植物として注目さ れ，最近では日本各地で「環境にやさしい植物」として の普及運動や植栽も盛んである．また，衣住の各分野に おいてケナフを利用した製品の開発も行われている31, 
4),5)が，食の分野では，その利用法の研究はあまりみら れない、しかし, ケナフ若葉は食用とされ6), ケナフの 一般成分として，カルシウム・食物繊維を多く含むこと より，著者らはケナフの食への利用開発に焦点を絞り， 本研究では, 調理法の検討を主な目的とし, ケナフ乾燥 粉末を穀物の粉に添加した場合における食感ならびに物 性への影響について検討した7),8).

\section{2. 方 法}

\section{(1) 試 料}

試料のケナフは，中国から輸入された「青皮 3 号」を 平成 10 年 5 月に神戸女子大学バイオ研究所で播種し, 11 月に採取したものを自然乾燥した，実験直前に，乾燥葉 を乳鉢で磨砕し，32メッシュのふるいを通し，粉末状に した.

材料の小麦粉は, 日清製粉(侏)製のカメリア(強力粉). 月（中力粉）・フラワー（薄力粉）を用いた. 白玉粉は, 三木製粉(侏)白玉粉を用いた。 上新粉は，三木穀粉(株)上新 粉を用いた。

\section{（2）試料の調製}

小麦粉 (強力粉 - 中力粉 - 薄力粉), 上新粉, 白玉粉 の粉類に調製直前に粉砕したケナフ乾燥粉末を粉類の 1 〜3\%の割合で添加した.

小麦粉を用いた調理として，パン，麺およびスポンジ ケーキを調製した，強力粉を用いたパンは，粉 $100 \mathrm{~g}$ に 対して, 水 $70 \%$, 食塩 $2 \%$, 砂糖 $3 \%$, イースト $1 \%$ の 割合で配合した.製法はナショナルホームベーカリー“食 パンメニュー”を用い, 強力粉にケナフ乾燥粉末を加え 均一にし, 水・食塩·砂糖・イーストを七ットし, ミキ シングおよび焼成を行ったものを試料とした.

中力粉を用いた麵は，粉 $100 \mathrm{~g}$ に対して，水 $50 \%$, 塩 $3 \%$ 割合で配合した．製法は中力粉にケナフ乾燥粉末 を加え均一にし，食塩水を加えて20分ミキシング（手ご ね 1 回 $/ 3$ 秒) を行い, 30 分小かした後, インペリア （sp 150）を使用して10回圧延し麵帯をつくり, 麵線と した後，1リットルの熱湯で15分間茹でたものを試料と した。

薄力粉を用いたスポンジケーキは, 粉 $100 \mathrm{~g}$ に対して, 砂糖100\%, 卵100\%で配合した. 製法は薄力粉にケナフ 乾燥粉末を加え均一にし, ふるいにかけ, 全卵と砂糖を 10分間ミキシング（ハンドミキサーtm-85）した後,

粉類を加えてケースに流し， $185^{\circ} \mathrm{C}$ のガスオーブンで 20 分間焼成したものを試料とした。

白玉粉を用いた団子は, 白玉粉にケナフ乾燥粉末を加
え均一にし, 粉 $100 \mathrm{~g}$ 対し水 $98 \%$ を加え, 10回こねて, 直径 $2.5 \mathrm{~cm}$ ·厚さ $1.5 \mathrm{~cm}$ の扁平な団子状に丸めた後, 1 リットルの熱湯でゆで，浮き上がってきたものを $5{ }^{\circ} \mathrm{C} の$ 冷水に 5 分間浸漬し，水分をきった後，試料とした。

上新粉を用いた蒸しカステラは粉 $100 \mathrm{~g}$ に対し, 砂糖 100\%，卵100\%を配合した。製法は卵白を 1 分30秒間ミ キシングし, 砂糖添加後30秒, 卵黄添加後さらに30秒 ミ キシングを行い, 上新粉にケナフ乾燥粉末を加え均一に したものを加え, ケースに流し, 蒸し器で15分間沸騰状 態を継続して蒸し, 試料とした。

\section{（3）テクスチャ一測定および色調測定}

硬さの測定には，山電社製レオメーター（RE-3305） を用いた。プランジャーは，アクリル樹脂製（49） w $13 \mathrm{xD} 30 \mathrm{xH} 25\left(30^{\circ}\right)$ 先端 $1 \mathrm{~mm}$ 幅平面仕上げのくさ び型を用い, MODE (gf), OPERATE, SPEED 1 $\mathrm{mm} / \mathrm{sec}$.をコンピューター解析した. 色調の測定には ミノルタ製カラーセンサーMCR一Aを用いた。食物繊 維の測定は NDF 法9)により行った. カルシウムの測定 は過マンガン酸カリウム滴定法10)により行った.

\section{(4) 官能検査}

官能検査は, 3 種類の試料（コントロールニケナフ 0 \%添加， 1\%添加，3\%添加）を準備し，それらの特性 (香り·苦味（党ぐみ）・硬さ・総合評価）について評 価し, 順位法 (ranking method)で検定を行った. 被験 者10名に調査用紙を配布し，クレーマーの検定により 5 $\%$ 有意差を求めた（表 1 ）.

\section{表 1 官能検查調查用紙}

官能検查

$$
\text { 年月日男·女 年齢歳 }
$$

3 種類の試料についてく香り・苦味 (えぐみ) · 硬さ・総合的な 颃いしさについて指示にしたがって順位をつけてください。

\begin{tabular}{|l|l|l|l|l|}
\hline & $0 \%$ & $1 \%$ & $3 \%$ & 指 示 \\
\hline 香り & & & & 弱いものから $1,2,3$ \\
\hline 苦味 (えぐみ) & & & & 苦いものから $1,2,3$ \\
\hline 硬さ & & & & 硬いものから1,2,3 \\
\hline 総合的なおいしさ & & & & よいものから1,2,3 \\
\hline
\end{tabular}

\section{(5) アンケート調査}

ケナフの知名度および用途について短期大学生 193 名 を対象に平成 11 年 5 月にアンケートにより調査を行っ た。

\section{3. 結果および考察}

ケナフの植物分類における位置付けを表 2 に, ケナフ 
表 2 植物分類におけるケナフの位置

CLassification of Kenaf

植物一種子植物門 (Dividion SPERMATOPHYTA)

被子植物亜門 (Subudividion ANGIOSPERMATE)

双子葉植物綱（Class DICOTYLEDONEAE）

離弁花類（APOPETALAE CHORIPETALAE）

オトギリソウ目群（HIPERICALES group

アオイ目 (Order Malvales

$$
\begin{array}{lcc}
\text { ホルトノキ科 } & \text { トロロアオイ属 } & \text { ケナフ } \\
\text { サルラエナ科 } & \text { (H. mulabilis }) & \text { (H. cannabinus) } \\
\text { シナノキ科 } & \text { エノキアオイ属 } & \text { ロゼル }
\end{array}
$$

アオイ科 フコウ属 (Hibiscus L) (H. sabdariffa)

(Family Malvacease)

$$
\text { フヨウ }
$$

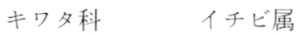

アオギリ科 キンゴジカ属

スキトペタルム科 サキシマハマボウ属（H. syriacus） ポンテンカ属分六ウ

(H. hamabo フウリンブッソウゲ

(H. schizopetalus)

クサフヨウ

(H. moschleulos) その他
知つている $8 \%$

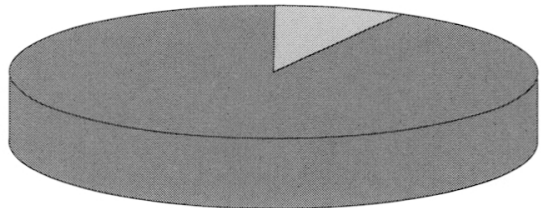

知らない $92 \%$

図 2 ケナフ知名度

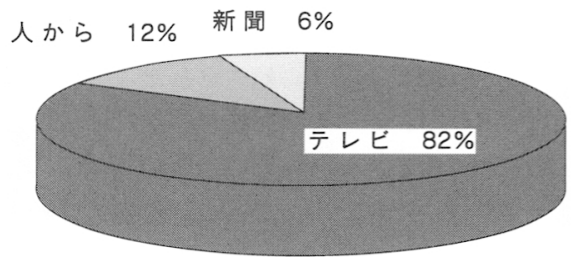

図 3 情報源

アンケートにより,ケナフの知名度などを調査した結 果，ケナフを「知っている」としたものは $8 \%$ ，「知ら

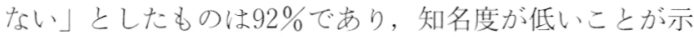
された（図 2 ）。亦た，「知っている」としたものについ て，どこで知ったかといら質問に対し，「テレビ」が82 $\%$ 之最も多く，次いで「人から」が $12 \%$,「新聞」が 6 \%で，テレビの影響が大さいことが示唆された（図 3 ).

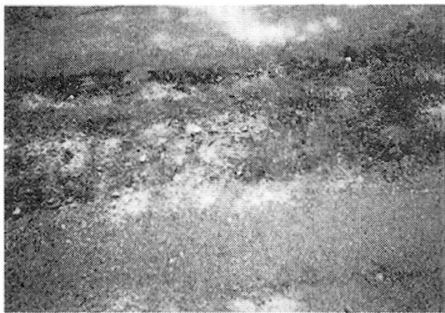

24 'th May

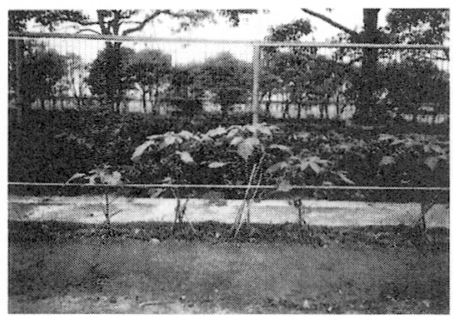

$30^{\prime}$ th June

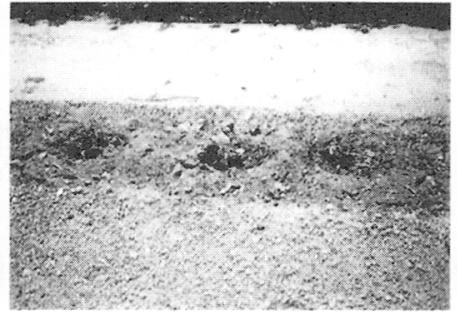

30 'th May

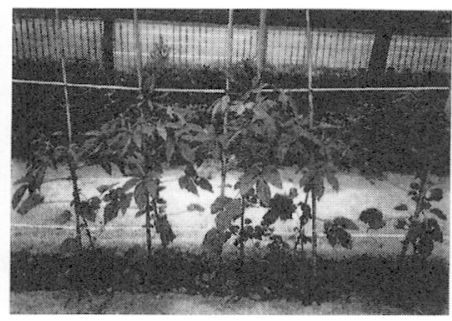

14 'th July

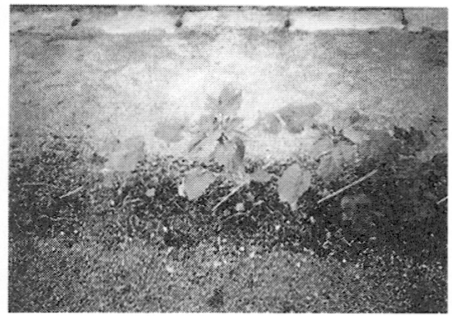

10 'th June

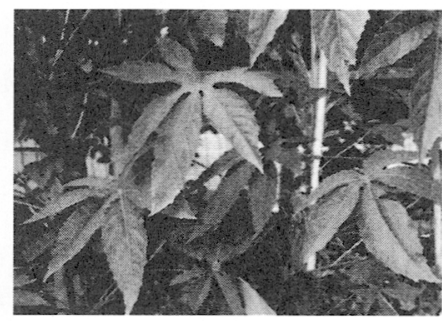

ケナフ葉

図 1 ケナフの成長過程

の成長過程を図 1 に示した。播種後約 2 か月で $1.5 \mathrm{~m} く ゙$ らいに成長し，成長につれて葉は，卵型から掌状に 3 5 本に開裂した。
さらに「ケナフは何に使われているか」を質問した結果, 「紙や名刺」が28\%,「壁紙」が28\%,「染料」が $6 \%$ で, 紙への利用のみが知られていることも判明した（図 4 ）. 


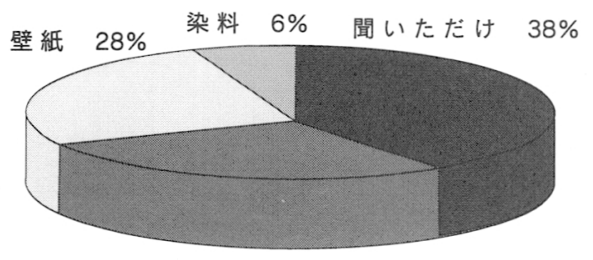

紙 ·名刺 $28 \%$

図 4 ケナフの用途

また「「ケナフ」を食べたことがあるかの質問では 100\%が「ない」と回答し, 食性については知られ ていないと考えられた。

そこで，ケナフの食性を検討するためにケナフの 粉末を粉類に添加し, 試料の調製を行った。四 5 に 調製結果, 表 3 に官能検査結果を示した.

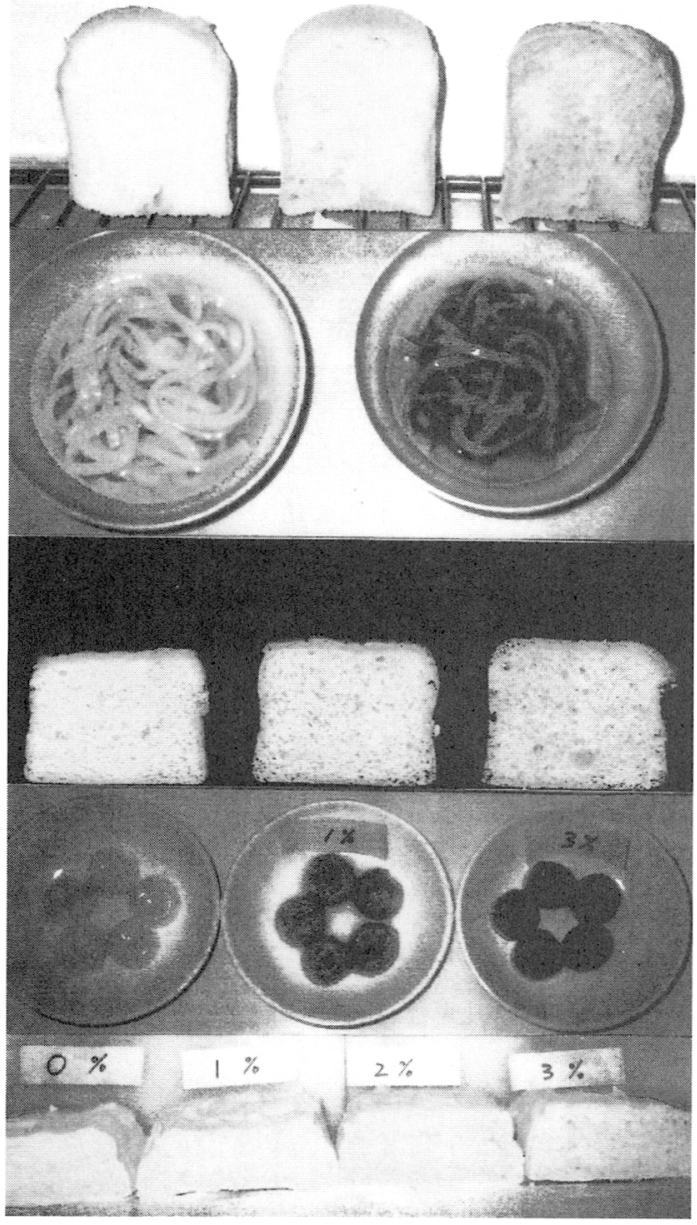

図 5 調整結果

上よりパン・らどん・ケーキ・白玉団子、蒸しカステラ
表 3 ケナフ乾燥粉末添加における官能検査結果（順位法）

\begin{tabular}{|c|c|c|c|c|c|c|c|c|c|c|c|c|}
\hline & \multicolumn{3}{|c|}{ 香り } & \multicolumn{3}{|c|}{ 苦味 (えぐみ) } & \multicolumn{3}{|c|}{ 硬さ } & \multicolumn{3}{|c|}{ 総合 } \\
\hline & $0 \%$ & $1 \%$ & $3 \%$ & $0 \%$ & $1 \%$ & $3 \%$ & $0 \%$ & $1 \%$ & $3 \%$ & $0 \%$ & $1 \%$ & $3 \%$ \\
\hline \multirow{2}{*}{ 食パン } & 15 & 15 & 30 & 30 & 20 & 10 & 10 & 24 & 28 & 18 & 12 & 30 \\
\hline & & & $*$ & $*$ & & $*$ & $*$ & & $*$ & & $*$ & $*$ \\
\hline \multirow{2}{*}{$\begin{array}{l}\text { スポンジ } \\
\text { ケーキ }\end{array}$} & 12 & 20 & 30 & 30 & 21 & 12 & 30 & 20 & 15 & 30 & 26 & 15 \\
\hline & $*$ & & $*$ & $*$ & & $*$ & $*$ & & & $*$ & $*$ & \\
\hline \multirow{2}{*}{ 蒸しカステラ } & 15 & 15 & 30 & 25 & 24 & 11 & 18 & 21 & 25 & 24 & 23 & 13 \\
\hline & & & $*$ & & & $*$ & & & & & & $*$ \\
\hline \multirow{2}{*}{ らどん } & 11 & 20 & 29 & 25 & 17 & 12 & 25 & 20 & 18 & 25 & 14 & 18 \\
\hline & $*$ & & $*$ & & & $*$ & & & & & $*$ & \\
\hline \multirow{2}{*}{ 白玉団子 } & 15 & 17 & 28 & 25 & 25 & 10 & 22 & 28 & 10 & 15 & 15 & 30 \\
\hline & & & $*$ & & & $*$ & & & $*$ & & & $*$ \\
\hline
\end{tabular}

$\mathrm{t}=3 \quad \mathrm{n}=10 \quad \mathrm{p}<0.05 \quad *: 5 \%$ 有意差

ケナフをパン生地に $3 \%$ 添加すると, 食感において舌 を刺激する苦みが感じられ，また，香りは干草臭が強く， 総合的に好丈れない傾向にあった。 ケナフの添加量を 1 \%にトげると，苦み・不快臭は減少し，1\%添加は $3 \%$ に比べ食感において有意に好まれる傾向にあった。

スポンジケーキにおいては，3\%添加では苦味は感じ るが総合的に最も好まれる傾向がみられた。

蒸しカステラにおいては，3\%添加では，香り・苦味 もやや感じられる程度であり, 総合評価において最も好 まれることが認められた。

麵については, $3 \%$ 添加では, 香り・味ともに有意に 強く感じられた。総合的には1\%は好をれる傾向にあり， 次いで $3 \%$ が好李れる傾向がみられた。

白玉団子では， $3 \%$ 添加では苦味や硬さが増し総合的 に有意に好李れない傾向がみられた。 $1 \%$ 添加では０\% とほぼ同様の傾向が見られ，有意差は得られなからた。

テクスチャー測定による解析の結果, 図6に示すよう に1〜3\%ケナフの添加量による硬さの差は, 食パン. スポンジケーキのよらな多孔質で, 水分量の少ない食品 では, ケナフの添加量が $3 \%$ に増加すると，1\%に比べ てやや硬さが減少する傾向がみられた。 子の上らな可塑性食品では， $3 \%$ 添加すると，1\%添加 に比べて硬くなる傾向が認められた．蒸しカステラのよ らな多孔質であるが蒸し加熱による水分量が高い場合 は, ケナフの添加による硬さの变化訬なかった．

表色測定によるLab 表色系の変化においては, ケナ フ添加量が増加寸ると, 緑の方向に色が濃くなり, $\Delta \mathrm{E}$ の值が増すことが認められた（図 7 ).

以上を総合すると 1 〜 \%の範囲で, ケナフ乾燥葉の 


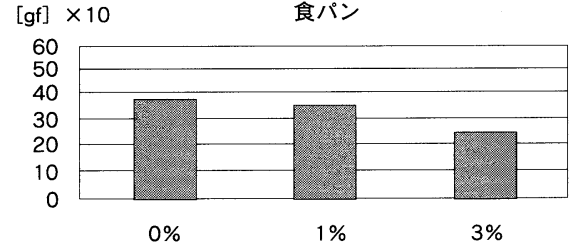

[gf] $\times 10 \quad$ 蒸しカステラ

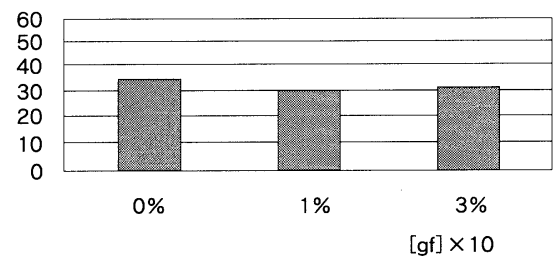

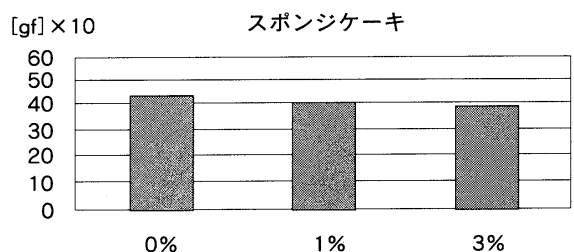

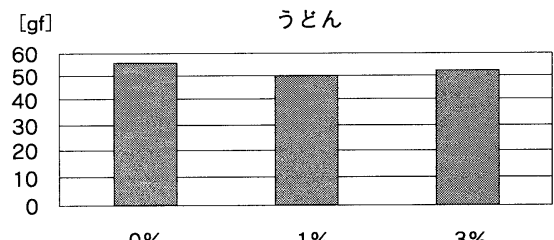

$0 \%$

白玉団子

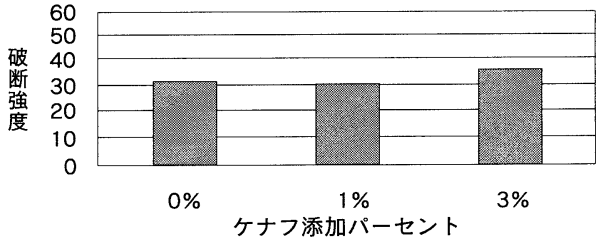

図 6 ケナフ添加による破断強度の変化

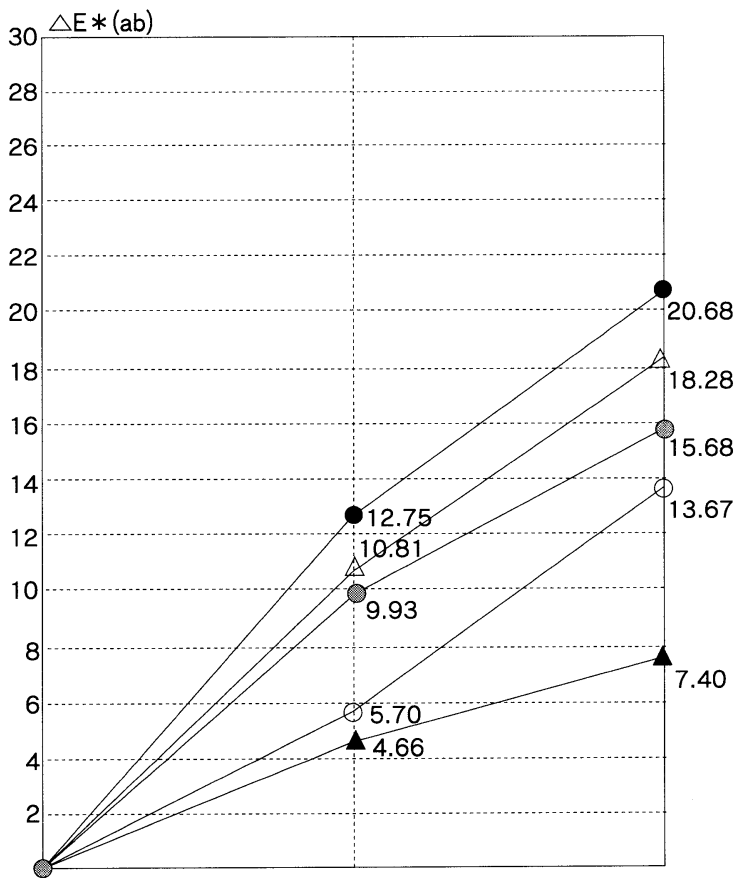
ケナフ添加パーセント

○ :食パン

・:うどん

○ : 白玉団子

$\triangle:$ 蒸しカステラ

図 7 ケナフ添加における表色測定の結果
粉類への添加が可能であることが示唆された.

ケナフ乾燥葉の成分を測定した結果，カルシウムは $641 \mathrm{mg} / 100 \mathrm{~g}$ で，食物繊維は26.35g/100g であった。 これらの值よりケナフ乾燥葉の添加による食品のカルシ ウムおよび食物繊維量の変化を図 8 に示した。麦粉に $1 \%$ ケナフ粉末を添加するとケナフ無添加の基本試料に 比ベ, カルシウムでは約1.6倍, 食物繊維では約 2 倍, $3 \%$ ケフ粉末を添加するとカルシウムでは約 2.8 倍, 食物繊維では約 4 倍の増加が見られた.

\section{要 約}

ケナフの乾燥葉粉末を粉類に添加し，その調理特性な らびに食物への利用の可能性を検討した.

1.ケナフの知名度をアンケート調査した結果， $8 \%$ と 知名度が低く, 食物への利用状沉について知る者は $0 \%$ であった。

2.ケナフを粉類に添加しパン, 麵, スポンジケーキ, 蒸しカステラ, 白玉団子を調製した結果, 1 ～ $3 \%$ 範 囲で利用可能であることが認められた.

3. 嗜好調査より，ケナフを $1 \%$ 添加が望ましいと考え ると, ケナフを添加しないものに比べると, カルシウム は約 1.6 倍, 食物繊維では約 2 倍の増加が期待できると 推察する. 

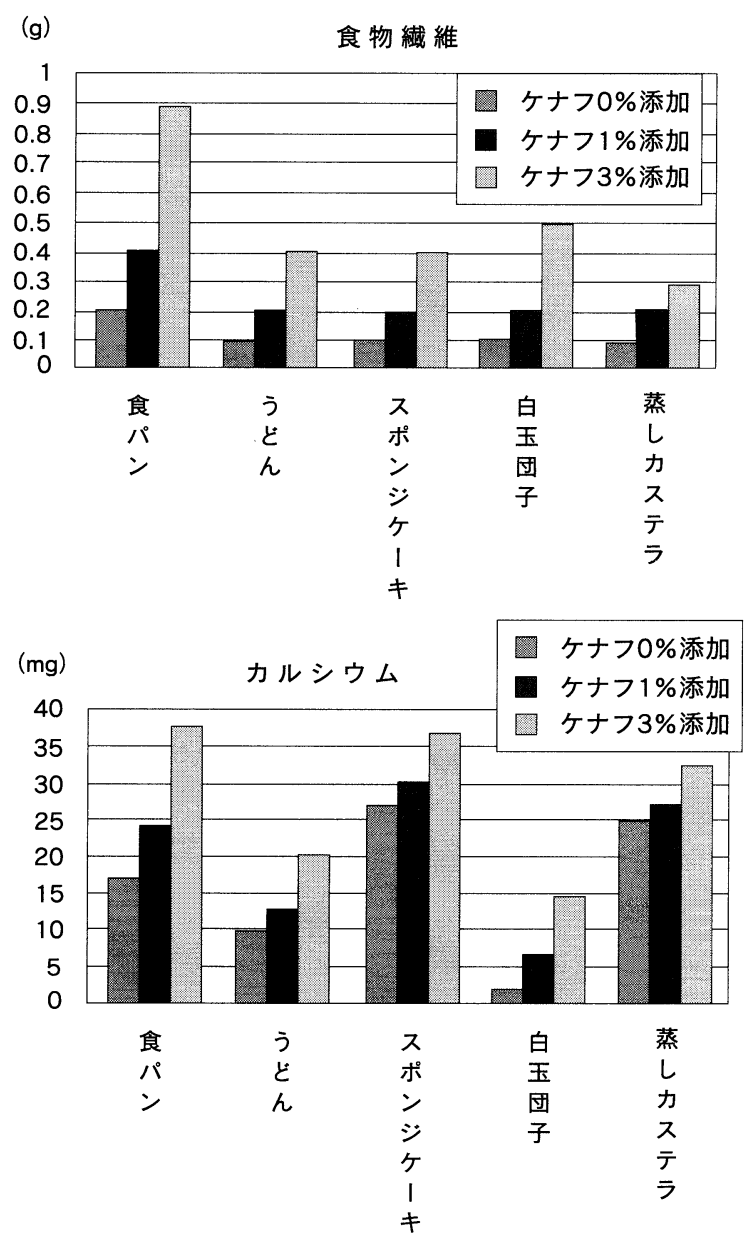

図 8 ケナフ添加におけるカルシウムおよび食物繊維量の比較（検 体量 $100 \mathrm{~g}$ )

$$
\text { 文献 }
$$

1）早水信弘：環境保全に役立つ新しい非木材資源“ケナ フの栽培·加工について，10（1998）

2）尾崎保夫, 安部 薫: 用水と廃水, 15, 9，5（1993）

3）稲垣 寛：緎維学会誌，52，5，3（1996）

4）稲垣 寛：機能紙研究会誌，33，37（1994）

5）稲垣 寛：食物と健康, 行吉学園出版, 1998 秋号, 8 (1998)

6）堀田 満他：世界有用植物事典, 平凡社, 525（1991）

7）大矢正昭：食品加工技術，15（3），53（1995）

8）小倉和恵 - 堀田千津子：日本食生活学会誌 9（3）, 21 (1993)

9）川端晶子：調理科学実験, 地人書館, 東京, 270 (1986)

10）渡辺忠雄 : 食品科学実験, 講談社, 東京, 95（1996） 